Rev. Adam Skreczko

Cardinal Stefan Wyszyński University

DOI: $10.15290 /$ rtk.2021.20.09

iD $0000-0002-1437-8923$

\title{
Pastoral Care of Vocations and Personal Identity
}

In its mission of evangelization, the Church has focused on pastoral care of vocations in recent years. Confronted with the many challenges facing civilization and the progressive secularization of the societies of materialistic Europe, the Church has been seeking appropriate methods, means, and formation strategies to help young people recognize their vocation. Undoubtedly today many formators and vocation animators are aware of the significant role that the psychological sciences play in the understanding human identity. God is always calling, but man alone can respond.

In the human formation and maturation process, a person has the opportunity to come to know himself and understand his own history. A person who has responded to God's call must also agree to ongoing long-term formation. From this point of view, personal accompaniment plays an important role, since no person is capable of progressing towards human and spiritual maturity alone.

Key words: personal identity, vocational ministry, psychology, pedagogy, counseling, self-narrative, education, accompaniment, Gaudete et Exsultate.

Pastoral ministry for vocations faces many challenges today. Recognizing a vocation and accompanying a young person in an individualized and personalized manner requires concrete preparation and adequate skills. Today especially, when the Church is experiencing a crisis in vocations, we are invited to focus on how to recognize a vocation and how to help foster its development. The central-and, indeed, indispensable-element in this process is to develop the entire personality. Those who care pastorally for vocations help an individual recognize the truth about himself and answer the question: "Who am I?" The proper response to this question depends on 
Pastoral Theology

what a person wants based on his personal development. This paper attempts to illustrate the role of pastoral care for vocations in aiding the individual in identifying and developing his personal identity during the formation process. This document examines what identity is from the point of view of Christian anthropology. The first part of this work deals with the topic of pastoral ministry for vocations and the human development of personality. In the second part, we present a series of pedagogical tools to aid in identity formation: the personal life project, personal accompaniment, self-narration, and the growth group. The conclusion discusses educational interventions that foster vocational maturation and assist the individual in reaching the objectives of formation, which are acquiring concrete competences and strengthening the human resources of the person responsible for the pastoral care of vocations. This research investigates in depth some constitutive elements of personal identity such as: encounter with one's self, the ability to create mature relationships with others, as well as an authentic intimate and spiritual relationship with God.

\section{An Analysis of Human Development}

We begin by studying the fundamental role of human development in a person's growth. Human development is a gradual process that encompasses personality development, which continues within the context of pastoral ministry for vocations. In order to proceed properly, it is necessary to have a thorough understanding of what constitutes the person, since he is both a human and a spiritual being. The human sciences, especially psychology, will help us in understanding what identity is.

\section{The construction of identity}

All pastoral activity is based on the proper understanding and image of man. Every life is a vocation, but pastoral ministry for vocations entails a particular way of life. The purpose of educational and formative intervention is to propose not a subjective but objective concept of man. An absolutely necessary and, indeed, imperative element of this task is to present the meaning of life as it is discovered in the realization of one's vocation. ${ }^{1}$ To begin, one might ask: "What is identity, and why has it become such an vital issue today?" The word "identity"

See M. O. Llanos, Servire le vocazioni nella Chiesa: pastorale vocazionale e pedagogia della vocazione (Roma: LAS, 2005), 209-2011. 
derives etymologically from the Latin adjective "idem," which means "the same:" I am myself because I am not another. Identity is

...a personal achievement as well as a social attribute. ... Society does not exist without individuals, nor do individuals exist without society. Identity is the answer to the question of who I am and who we are. Who I am also means to whom I belong, from where I come, and where I belong, thus [implying] dependence on a community as well as autonomy. ${ }^{2}$

A very important task is to define the end identity toward which identity should be formed and whether or not identity is subject to transformation. In his research, $R$. Regni proposes an identity of dialogue, since we cannot realize ourselves outside of a relationship with both ourselves and with others. ${ }^{3}$ Identity as the image of one's own self as a person who has achieved emotional equilibrium and a fair degree of social recognition plays a fundamental role in the way all of the processes and functions of the personality take place. The "I" structure plays the primary and constitutive role of identity. According to Gordon Allport, the ego expresses itself in seven ways: bodily sense, self-identity, ego-enhancement, ego-extension, rational activity, selfimage, and propriate striving. ${ }^{4}$ Psychology makes a distinction between the actual ego and the ideal ego. The former concerns the way in which a person manifests and presents himself, and this applies to emotions, behavior, hidden feelings as well as the way in which a person perceives himself according to the opinion of others. As far as the latter, it is the vision of oneself according to the ideal self, which can be divided into personal and institutional. In the former, a person chooses values and projects who they want to be. ${ }^{5}$ Amedeo Cencini explains that by identity "we mean the sense of inner unity and continuity that persists over time and in different circumstances combined with the ability to maintain solidarity with a realistic system of values. ... The opposite of identity is a lack of self-esteem, which manifests in shame; a lack of trust, which manifests in doubt; a lack of stability, which manifests in indecision; and a lack of value reference, which manifests in existential emptiness." ${ }^{6}$ Personal identity "is a complex and multidimensional

2 R. Regni, "Identità e educazione. Nuove sfide per la pedagogia interculturale," Pedagogia e vita. Rivista di problemi pedagogici educativi e didattici 78 (2020): 17.

See Ibid, 24-27.

See A. Cencini and A. Manenti, Psicologia e formazione (Bologna: Centro Editoriale Dehoniano, 1985), 111-114.

Ibid, 117-118.

Ibid, 119. 
phenomenon. Psychologists have tried to clarify the various aspects of this reality and, to this end, have studied psychosexual identity a lot recently. They have also stressed the importance of psychosocial identity. Questions about psycho-affective identity, national identity in an increasingly multi-ethnic and multi-racial Europe, as well as the identity of the immigrant, etc. have been raised. Rarely, however, do we encounter the concept of personal identity, and even less so do we hear about the concept of psycho-spiritual identity. And yet, this idea is an indispensable stage in the construction of man's image."

Pastoral Theology

\section{Identity development in pastoral ministry for vocations}

A critical examination of society today reveals that it is highly efficient. The development of new information technologies and the possibility to travel anywhere make it possible to live at a fast pace and with every comfort. Yet, the need to discover (or re-discover) the meaning of life is more pressing than ever. At times, we observe that man seems to have lost the "need to live" and is driven by a kind of "thirst for learning" and a search for life's deeper meaning. Man seeks authenticity and self-development through values. ${ }^{8}$ In the pastoral care of vocations, especially and primarily of young people,

...the challenge that pedagogy faces today is precisely enhancing the construction of the self, but always within a community. The community can no longer represent a place where members feel trapped by the will of their superiors and the group, or where their destiny is decided without due regard for their freedom. Instead, this community should be the space vital to every person to live out an authentic relationship with other human beings. ${ }^{9}$

Every community, every environment where growth occurs-the family, church, work, school, peers, social centers, and gathering places-have a duty and mission to support, foster, and form the individual. Only in this way can a young person develop his own vision of the world and of himself, and then find his place and role in life. Every person needs support and direction. The human person is like an unknown realm. Pastoral ministry for vocations must help people

$7 \quad$ M. Szentmártoni, "Volto e volti: aspetti psico-spirituali dell'identità personale," Gregorianum 82, no. 3 (2001): 457.

See V. Balzano, "Educazione e welfare: la persona e la sua identità come antidoto alla deprivazione antropologica dell'era postmoderna," Pedagogia e vita. Rivista di problemi pedagogici educativi e didattici 78 (2020): 144-145. 
understand who they are and then give them the necessary tools to present and relate their individual vocations to themselves. Pastoral ministry can become a bridge and means of communication to feel within oneself - in the depths of one's soul-where the voice of conscience is and the only place where it is possible to rediscover God's election and call. ${ }^{10}$

\section{A Selection of Pedagogical Tools for Identity Formation}

Various helpful tools that assist in the process of identity development exist. Man shapes his personality through self-awareness and in his relationship with others, in social life. The discovery and realization of one's vocation, which occur over time, are essential elements. This realization takes place in relation to others, meaning within the family or social group, at school, or in church. Below are only a few means by which a person can develop his identity.

\section{Personal life project}

The Church wants to put Christ's mission into practice by offering a formation adapted to the needs of our times. This project is implemented by a formation plan that points toward the path to be followed. In fact, certain formation processes that are indispensable in preparing young people well contain the following key elements: a clear concept that welcomes suggestions, ideas, recommendations, requests. The need for a project that encompasses formation and training becomes evident when one analyzes a situation that involves both theoretical and practical levels. Without a well-organized structure and specific methodology, young people cannot be trained properly. Above all, good guides are needed as well as specific measures, effective methodologies, and useful teaching tools. The project entails the training structure, while the pathway indicates the direction. The project and the pathway both serve to organize the community and are a useful framework in which to implement educational policy and training strategies.

$10 \quad$ See E. Giuseppe; A.D. Savino, "L'educazione all'identità come scoperta della coscienza e della cultura della persona," Pedagogia e vita. Rivista di problemi pedagogici educativi e didattici 78 (2020): 161-170. 


\section{Personal accompaniment}

Mario Oscar Llanos stresses that vocational discernment and accompaniment must involve the whole person. The development process is and must be integrated. The four dimensions of man: "human, spiritual, cultural, and missionary are not 'independent areas; they are interdependent, intercommunicative, interconnected and, therefore, should never be considered individually, but rather together, in the unity of the person." 11

In our society, real in-person relationships are being supplemented (and even supplanted) by virtual relationships that take place through digital channels. The use of the Internet and social media is a real challenge for formators, who must be vigilant about this dimension of communication and who must pay particular attention to moral and socio-psycho-pedagogical aspects of these means of communication. The human sciences, particularly psychology and Christian anthropology and pedagogy, are of help in this regard because they provide numerous tools for formation such as personal accompaniment, communal accompaniment, psychological assessment, therapeutic accompaniment, and personal work. Needless to say, the human dimension requires the utmost consideration today.

\section{Self-narration}

Self-reflection plays a very important role in every person's life. Everyone seeks the meaning of life. When identified properly, both positive and negative past experiences can give value and meaning to life itself. Self-narration is a helpful tool in this process because it enables "otherwise silent experiences to speak. Sometimes we understand our experiences better if and when we tell others about them not only because the listener can interpret them back to us better than we can, but also and simply because we have articulated these experiences. Narration liberates our experience from silence, from communicative isolation, and this means freeing them from their hidden meaning and releasing their vitality. Storytelling can 'bring life into focus.", 12

Narrating one's life is not a narcissistic or purely subjective act. Rather, it is an opportunity to see one's reflection in the mirror, so to speak, and to open up about one's life to others. Mutual trust, intimacy, and kindness between the one being accompanied and the

\footnotetext{
$11 \quad$ M. O. Llanos, Servire le vocazioni nella Chiesa, 252-253.

12 A. Spadaro, "La narrazione come principio di libertà," La Civiltà Cattolica 158, no. 3765, 5 maggio $2007,227$.
} 
accompanier are crucial in this process. Self-understanding as well as identifying one's emotions, struggles, and human relationships-in essence, interpreting one's life-are all very important. All of this must take place in an atmosphere of complete freedom and total trust. The following retrospective methods can be used to help a person achieve self actualization: narrating one's autobiography, the use of literary texts such as the Holy Scriptures, and a diary in which a person can record and interpret his experiences through the experience of others. ${ }^{13}$

A person needs a space to express his different emotions, inner life, and personal thoughts and reflections. If an individual has repressed and relegated inner conflicts or negative experiences to the subconscious, then narration provides a means by which he can discover the truth about himself. A lack (or inability) of self-reflection often leads to psychological problems. Yet, inner struggles are often the source of a wealth of information: "Some forms of psychic discomfort can also be interpreted as the ego protesting against an inner imprisonment. Affectivity, imagination, and relationships are powerfully present in man from his earliest years, but without adequate instruction, they tend to go astray."14

\section{Growth within a group}

Modern psychology has developed various theories about the role of peer groups in personality formation and development. Pastoral ministry for vocations takes place primarily within a group and among other people. As a social being, man can develop only in a group. The human person grows through experiences and events. Being in a formation group, for example, in church or at school, helps one to grow in self-awareness. There are several factors that aid in an individual's personality development, especially in forming healthy relationships with others. Peer groups teach shared responsibility and foster the ability to recognize the needs of others through feedback from others. Without a group that helps a person grow, relate to others, and build interpersonal relationships, the human person cannot develop

\footnotetext{
13 See G. Tacconi, "La narrazione di sé," in Formazione affettivo-sessuale: itinerario per seminaristi e giovani consacrati e consacrate, eds. P. Gambini, M. O. Llanos, and G. M. Roggia (Bologna: EDB, 2017), 303-309.

14 G. Cucci, "Narrazione e senso della vita," La Civiltà Cattolica 161, no. 3848, 16 ottobre 2010, 166.
} 
Pastoral Theology

psycho-emotionally. ${ }^{15}$ Every person who is involved in pastoral ministry for vocations must help young people in their self-realization because "In adolescence, the young person cuts ties from the safe harbor of the habits of childhood and, endowed with a sense of omnipotence, 'sets out to sea' on a voyage full of promise and unexpected possibilities. Separation from first ties and the creation of new ones through the social family (i.e. the group) are characteristic elements of this process. The adolescent thus reworks his identity in relation to categories that qualify his vital experience: space, body, sex, time, interiority, abstract thought, search for meaning, and planning. The adolescent rides his life, which is based on these categories, like a 'surfboard' on the intoxication waves of the sea of life with the sense of freedom that has been achieved with difficulty. The orientation of the surfer presupposes that he has assumed responsibility little by little, embodies a matured solidarity, and has directed his energies to personal fulfillment according to coordinates that are constantly fluctuating in daily life." 16

\section{Educational intervention}

The main objective of educational intervention is to help the person discover his vocational path for himself. The person, however, is not alone on this path. Educators and formators are always aware that the development of a young person's identity regardless of age is a complex process that occurs gradually and at different times for each person. The educational intervention presented below speaks of the three aspects that are essential for vocational formation: personal transformation, a relationship with others, and a personal relationship with God.

\section{Personal transformation}

Every formation activity seeks to achieve a specific objective. Formation provides the means and methods for growth, and pastoral ministry for vocations, in particular, is meant to help the person being formed to discover who he is and where he is going: the more he discovers the meaning of his vocation, which is to set out on the path

15 SeeR.Mastromarino, "Il gruppo esperienziale," in Formazione affettivo-sessuale: itinerario per seminaristi e giovani consacrati e consacrate, eds. P. Gambini, M. O. Llanos, and G. M. Roggia (Bologna: EDB, 2017), 295-302.

16 M.O. Llanos, „Giovani, Vocazione, Realizzazione personale,” Salesianum 79 (2017): 303-304. 
towards holiness, the more he experiences happiness and personal fulfillment. Formation contributes to a person's development, to his so-called "transformation" to maturity. This must always take place in an atmosphere of freedom.

In explaining what freedom is, A. Cencini and A. Manenti claim that total freedom does not exist because man is conditioned by various factors, among which are determinism and relative freedom, throughout life. The relationship between these two factors depends on environmental conditions and above all on conscious and unconscious attitudes. ${ }^{17}$ We must remember that freedom is a means of preserving both physical and mental health. Allowing sufficient space so that a person can act freely as a means of growth is something that educators must always respect at every stage of education. ${ }^{18}$ In our postglobalized world, where there is a great deficit of lasting and valuable relationships, the educator (or vocations promoter) should further the pedagogical aims to be authentic; to foster a sense of transcendence; to activate a young person's potential; to educate so as to enable the person to make mature decisions that will help him grow; to provide formation in ethics; and to cultivate a sense of beauty. ${ }^{19}$

\section{Encounter with others}

Every vocation can only develop within a community and is always for others. The vocational project comes to fruition through the love of neighbor, which is inextricable from the love of God. Man, as a relational being, needs a social life. ${ }^{20}$ The capacity to create interpersonal relationships is always connected with the capacity to love because: "it is a simple adventure of the heart that is never fully complete. Love has to grow and expand according to the capacity and depth that each person develops. Therefore, education in love is indispensable. Each person's story, after all, is driven by his or her own equal needs to love and be loved." 21

17 See A. Cencini and A. Manenti, Psychologia i formacja (Kraków: WAM, 2002), 336.

See J. Dewey, Esperienza e educazione (Milano: Raffaello Cortina Editore, 2014), $53-54$.

See M. O. Llanos, “Giovani, Vocazione, Realizzazione personale,” 313-318.

See Catechism of the Catholic Church (Roma: Libreria Editrice Vaticana, 1999), sec. $1878-1879$.

21 See G. M. Roggia, "Si può fare...5 - Accettare di essere amati," Vocazioni, 5 ottobre 2011, 5 . 


\section{Relationship with God}

Religious experience plays a significant role in the discovery of one's identity. Human life is not only what we can describe as the material world. Human development also takes place through a person's experience of God-"a certain contact that human consciousness can have with God: in a derivative sense, it is the awareness of God's action in the soul, of the soul's aspiration and movements toward union with God." ${ }^{2}$ Spiritual discernment is also necessary to discover one's vocation. It is not enough to make strenuous efforts-always and only human-to develop educational and self-development programs because

Pastoral Theology

[s]piritual discernment does not exclude existential, psychological, sociological, or moral insights drawn from the human sciences. At the same time, it transcends them. Nor are the Church's sound norms sufficient. We should always remember that discernment is a grace. Even though it includes reason and prudence, it goes beyond them; for it seeks a glimpse of that unique and mysterious plan that God has for each of us, which takes shape amid so many varied situations and limitations. It involves more than my temporal wellbeing, my satisfaction at having accomplished something useful, or even my desire for peace of mind. It has to do with the meaning of my life before the Father Who knows and loves me, with the real purpose of my life, which nobody knows better than He. Ultimately, discernment leads to the wellspring of undying life: to know the Father, the only true God, and the One Whom He has sent, Jesus Christ (cf. Jn 17:3). ${ }^{23}$

All endeavors related to vocations must take place on three levels: anthropological, educational, and pastoral. The first is based on the image of man, which prompts a person to ask himself: "Are we able to discover man's true face in God?" The educational area, in turn, serves to help young people discover the meaning of life and gradually enable them to evaluate reality correctly. Today, in our society, which is permeated by subjectivism, people are often unable to find true and objective values such as transcendence and ethics. Young people in particular need spirituality that gives meaning to life and serves to integrate. The experience of God takes place in community and in relationship with others. ${ }^{24}$ Everyone wants to find the path to happiness, especially the happiness that God offers because

God has a plan for each person. Discovering this divine plan for one's life means finding one's mission, one's charism. On a psychological

\footnotetext{
$22 \quad$ J. M. Garcia, Teologia spirituale (Roma: LAS, 2013), 339.

23 Francis, Gaudete et Exsultate (Roma: Libreria Editrice Vaticana, 2018), sec. 170.

24 See M. O. Llanos, "Servire le vocazioni nella Chiesa," 211-218.
} 
level, the meaning of vocation is articulated on three levels: who I must become according to God's plan; how to become what I must become; and, what I must do for God and for others. The first question refers to the acceptance of our selves. No one exists by chance; no one is a man or a woman by chance, etc. The second question refers to 'how' to realize God's creative plan and is usually articulated in three 'states of life': marriage, consecrated life, or singlehood. All three states are equal, since they are capable of guaranteeing the fulfillment of the whole person. ${ }^{25}$

\section{Conclusion}

Man is a complex being made up of body and spirit. According to the old adage "in medio virtus [virtue lies in the mean]," man cannot be considered from a purely psycho-sociological or spiritual point of view. Just as man is complex, so too is pastoral ministry. Today's formators and educators are called to help young people discover their own identity. This paper attempts to show how pastoral care can aid in the development of a person's identity. Rather than presenting a detailed analysis of how the personality is formed, this paper focuses on illustrating what the personality is and pointing out possible educational means to develop the personality adequately, such as personal accompaniment and support. Young people are seeking a life project, but they need space and resources that will foster their growth and maturation. Personal accompaniment plays an invaluable role in this process. Self-narrative is another very important tool in pastoral ministry for vocations; for, today's postmodern and post-globalized society makes it is difficult to reflect on one's life. Only by living consciously can a person assess events, ascribe meaning to them, and discover the purpose and value of life.

Pastoral work never takes place in isolation. The community of the family, church, school, peer groups, and other centers and gathering places are privileged environments where formation and education occur. Man is called to enter into in human relationships and can develop best only if he is rooted in a network of relationships: remaining outside a peer group, which provides opportunities for personal development, often proves destructive. The formation and education process leads to personal development, which is called "conversion" in spiritual language. The process of self-formation always takes place not only in relation with oneself and others, but also in a personal and

$25 \quad$ M. Szentmártoni, "Volto e volti," 465. 
intimate spiritual relationship with God. This paper conveys how the field of research on identity is broad and how the concept of identity itself is an indispensable tool in vocational accompaniment. Psychology possess the proper expertise and tools of which pastoral ministry for vocations should make ready use in order to better understand young people and, thereby, accompany them effectively on their formative journey.

\section{Bibliography}

1. Balzano, Vito. "Educazione e welfare: la persona e la sua identità come antidoto alla deprivazione antropologica dell'era postmoderna." Pedagogia e vita. Rivista di problemi pedagogici educativi e didattici 78 (2020): 135-149.

2. Catechism of the Catholic Church. Roma: Libreria Editrice Vaticana, 1999.

3. Cencini, Amedeo, and Alessandro Manenti. Psicologia e formazione. Bologna: Centro Editoriale Dehoniano, 1985.

4. Cencini, Amedeo, and Alessandro Manenti. Psychologia i formacja. Kraków: WAM, 2002.

5. Cucci, Giovanni. "Narrazione e senso della vita." La Civiltà Cattolica 161, no. 3848,16 ottobre 2010.

6. Dewey, John. Esperienza e educazione. Milano: Raffaello Cortina Editore, 2014.

7. Pope Francis. Gaudete et Exsultate. Roma: Libreria Editrice Vaticana, 2018.

8. Gahungu, Méthode. Formazione permanente dei presbiteri. Roma: LAS 2008.

9. Garcia, Jesus Manuel. Teologia spirituale. Roma: LAS, 2013.

10. Giuseppe, Elia, and Anna Daniela Savino. "Leducazione all'identita' come scoperta della coscienza e della cultura della persona." Pedagogia e vita. Rivista di problemi pedagogici educativi e didattici 78 (2020): 160-184.

11. Llanos, Mario Oscar. "Giovani, Vocazione, Realizzazione personale." Salesianum 79 (2017): 303-327.

12. Llanos, Mario Oscar. Servire le vocazioni nella Chiesa: pastorale vocazionale e pedagogia della vocazione. Roma: LAS, 2005.

13. Mastromarino, Raffaele. "Il gruppo esperienziale." In Formazione affettivo-sessuale: itinerario per seminaristi e giovani consacrati e consacrate, edited by P. Gambini, M. O. Llanos, and G. M. Roggia, 295-302. Bologna: EDB, 2017.

14. Regni, Raniero. "Identita' e educazione. Nuove sfide per la pedagogia interculturale." Pedagogia e vita. Rivista di problemi pedagogici educativi e didattici 78 (2020): 14-35.

15. Roggia, Giuseppe Mariano. "Si può fare...5 - Accettare di essere amati." Vocazioni, 5 ottobre 2011.

16. Spadaro, Antonio. "La narrazione come principio di libertà." La Civiltà Cattolica 158, no. 3765, 5 maggio 2007. 
17. Szentmártoni, Mihály. "Volto e volti: aspetti psico-spirituali dell'identità personale." Gregorianum 82, no. 3 (2001): 457-475.

18. Tacconi, Giuseppe. "La narrazione di sé." In Formazione affettivo-sessuale: itinerario per seminaristi e giovani consacrati e consacrate, edited by P. Gambini, M. O. Llanos, and G. M. Roggia, 303-309. Bologna: EDB, 2017. 